\title{
TEXAS COMMUNITY PROPERTY LAW: CONSERVATIVE ATTITUDES, RELUCTANT CHANGE
}

\author{
JOSEPH W. MCKNIGHT*
}

\section{INTRODUCTION}

Reform of Texas family property law has been significantly restrained by the conclusion of the Supreme Court of Texas in 1925 that the marital property system is constitutionally defined. ${ }^{1}$ If the court felt that recourse to the state constitution was required to save the underlying doctrine of Texas marital property from being subverted by ill-conceived legislative efforts to improve the legal lot of married women, ${ }^{2}$ it may have been correct. A major tenet of the system was thereby preserved, ${ }^{3}$ and subsequent pressures for legislative change were removed due to reduced legislative power. Without the decision of 1925 , however, the system could have been developed very differently.

While Texans have gradually lifted most fundamental inhibitions by amending the constitution itself, the Texas Supreme Court's failure to formulate consistent principles of matrimonial property law has encouraged resort to statutory reform as the principal means of legal modernization. On its face, the Texas Constitution gave no hint of the interpretation put upon it in 1925. It seemed merely to define the wife's separate property. ${ }^{4}$ But before the language of the constitution was formulated in 1845 , a correlative relationship between

Copyright $\odot 1993$ by Law and Contemporary Problems

*Professor of Law and Larry and Jane Harlan Faculty Fellow, Southern Methodist University.

The author thanks his literary partner, William A. Reppy, Jr., for his advice in preparing this essay for publication.

1. Arnold v. Leonard, 273 S.W. 799 (Tex. 1925); Gohlman, Lester \& Co. v. Whittle, 273 S.W. 808 (Tex. 1925); Cauble v. Beaver-Electra Refining Co., 274 S.W. 120 (Tex. 1925). The authors of the constitutional provision meant it to serve as a deterrent to legislative tampering with the rights of married women. See William F. WeEks, Debates of the TeXas [Constitutional] ConVENTION $597,601-02(1846)$. But the judicial interpretation of 1925 greatly magnified the scope of the provision.

2. Prior to the early years of the twentieth century, the wife had almost no role under law in the control of marital property. Reform began in 1911, not by bringing her into the management of the community, but by authorizing her to become a sole trader on her separate account. See infra notes 7072 and accompanying text. Then, in 1915, the bulk of the wife's recovery for personal injuries- which had been all community property under prior case law-were reclassified as her separate property. 1915 Tex. Gen. Laws $251, \S 1$. This cutting back of the community continued in 1917 with legislation declaring rents and profits of the wife's separate property (as well as the husband's) to be separate. 1917 Tex. Gen. Laws 436, \& 1; see infra text accompanying notes 79-80.

3. The Hispanic principle that the revenues from separate property are community had been statutorily abandoned in 1917. See supra note 2.

4. See infra note 31 . 
separate and community property had existed. ${ }^{5}$ The Reception Act of 1840 had specifically defined the common estate of spouses as the property other than that defined as their separate properties. ${ }^{6}$

The Act of 1848, from which all later definitions of community property were derived, stated the definition similarly ${ }^{7}$ and restored the Hispanic balance between separate and community property from which the 1840 statute had departed. After 1848 the small number of applicable statutes conformed to Hispanic principles and left only a few novel issues to be decided judicially by application of Anglo-American principles. As the draftsman of the constitutional definition and author of many of the early opinions on the subject, ${ }^{8}$ the state's first Chief Justice, John Hemphill, forged the principal links between the Hispanic past and the future law.

The evolution of the system can be divided into three major periods of development. $^{9}$ The first period began with legislative perpetuation of the Spanish law of marital property during the 1840s and continued until 1913 with the courts maintaining full control of the system. The second period (which began in 1913 and ended in 1967) was active and chaotic, with the legislature and the courts both struggling to adjust the "constitutionalized" system to a changing society. The final period runs from $1967^{10}$ - when gender discrimination was eliminated in a major reform-to the present. This last quarter century has been marked by vigorous efforts to deal with old and new problems, though little in the way of philosophical bases can be distilled from these developments. Texas spouses now enjoy some-but by no means unlimited ${ }^{11}$-freedom in dealing with their marital property inter se, but neither the supreme court nor the legislature adheres to a pro-community or a pro-separate property stance.

Over half a century ago, Professor Richard Powell, a major force in American property law and negative critic of the principle of community property, characterized the system as a "conservative power"12 of familial

5. 1839-1840 Tex. Gen. Laws 3, \$\$ 3-4, at 4, reprinted in 2 H.P.N. GammEL, LAwS OF TEXAS 177 , $178(1898)$.

6. Id. $\S 4$, reprinted in 2 GAMMEL, supra note 5, at 178 .

7. 1847-1848 Tex. Gen. Laws 77,83 at 78 , reprinted in 3 GAMMEL, supra note 5 , at 77,78 .

8. See Scott \& Solomon v. Maynard, Dallam 548 (Tex. 1843); Smith v. Smith, 1 Tex. 621 (1846); Cartwright v. Hollis, 5 Tex. 152 (1849); Hollis v. Francois, 5 Tex. 195 (1849); Edington v. Mayfield, 5 Tex. 363 (1849); Wood v. Wheeler, 7 Tex. 13 (1851); Huston v. Curl, 8 Tex. 239 (1852); Christmas v. Smith, 10 Tex. 123 (1853); Wright v. Hays' Adm'r, 10 Tex. 130 (1853); Stramler v. Coe, 15 Tex. 211 (1855); Smith v. Strahan, 16 Tex. 314 (1856); Higgins v. Johnson's Heirs, 20 Tex. 389 (1857).

9. This same division is made in Joseph W. McKnight, Texas Community Property Law-Its Course of Development and Reform, 8 CAL. W.L. REV. 117 (1971), revised in ESSAYS IN THE LAW OF PROPERTY PRESENTED TO CLYDE EMERY 30 (1975).

10. The Matrimonial Property Act of 1967 became effective on January 1, 1968. The drafters' commentary on the proposed act is reprinted in Commentary to the Matrimonial Property Act of 1967, 17 TEX. TECH L. REV. 1319 (1986).

11. Joseph W. MCKNight \& William A. RePpy, JR., TeXas Matrimonial Property Law 20 (1983) lists six possible provisions for characterization of property as community or separate that, under present law, would be void if included in an antenuptial contract or a similar contract between spouses.

12. Richard R.B. Powell, Community Property-A Critique of Its Regulation of Intra-Family Relations, 11 WASH. L. REV. 12, 38 n.125 (1936) (quoting GEORGE MCKAY, A TREATISE ON THE LAW 
orientation. It is, but judicial attitudes in Texas have undergone a change of focus. From the early decisions of John Hemphill through the 1925 decision constitutionalizing marital property law, the apparent judicial goal was to preserve the old, Hispanic principles and thus to protect the wife's interest in the co-owned marital estate while giving her almost no role in its management. In recent decades, the Texas Supreme Court has faced a series of issues with no solution in the Hispanic past. Old Spanish law did not recognize divorce for postmarital causes; therefore, no traditional answers were provided for the questions posed by the increasing incidence of marital breakdown. Other new issues have arisen because the judiciary has had to deal with types of property interests, such as employees' retirement pension plans, that did not exist in the Hispanic legal setting. Until 1987, the Texas Supreme Court was, however, prevented by statute ${ }^{13}$ from reviewing questions arising on divorce that did not pose precedential, statutory, or constitutional conflict, and the court was sometimes inclined to shield itself from consideration of such matters when it could use the statute to do so.

Since 1925 , the legislature has generally been conservatively inclined in addressing matters of family property law. Although in 1967 Texas was the first community property jurisdiction in the United States to eliminate gender discrimination from the laws of community management, the solution chosen is not now viewed as progressive. Texas's concepts of sole and joint management of community property ${ }^{14}$ are built on the notion of two communities dating from $1913 .{ }^{15}$ None of the other eight community property states has followed Texas in removing gender discrimination from the rules of management in this way. All other community property states have chosen a partnership approach, usually described as an "equal" management system. ${ }^{16}$

\section{II}

\section{STAGE I: ADOPTION OF THE COMMUNITY REGIME BY CONSTITUTION AND} STATUTES WITH JUDICIAL RECOGNITION OF ITS HISPANIC ROOTS

As a liberal response to the repressive attitude of English law toward the property rights of married women, in 1840 the Congress of the Republic of Texas enacted a definition of the elements of marital property law largely derived from Spanish doctrine embodied in the Louisiana Civil Code of $1825 .{ }^{17}$ The

OF COMmunity Property $\$ 73$, at 65 (2d ed. 1925)). See also 4A Richard R. POWell, ReAl PROPERTY \& 625[3] (1992).

13. TEX. GOV'T CODE ANN. $\$ \$ 22.001,22.225$ (West 1988).

14. As used here, as in Texas practice, the term "joint" management means that both spouses must act in concert to perform a valid act in relation to a particular property interest. See TEX. FAM. CODE ANN. \& 5.22(b), (c) (West 1993); MCKNIGHT \& REPPY, supra note 11, at ch. 9.

15. See infra text accompanying notes 73-74.

16. This term means that either spouse acting alone can deal with a community asset. See WILLIAM A. RePPy, JR. \& CYNTHIA SAMUel, COMmUNITY PROPERTY IN THE UNITED STATES 14-1 (3d ed. 1991).

17. See McKnight, supra, note 9, at 32. Insofar as this definition did not comport with the Hispanic model, the departure was cured by the statutes of 1848 . See supra note 7. 
centerpiece of the Spanish system was the marital partnership, to which both spouses contributed the profits of their wealth and efforts and in which each acquired half ownership in all gains accrued during marriage. ${ }^{18}$ Unlike the husband, the wife could not assert her half interest in those gains of the marriage until the marriage was dissolved by the husband's death, ${ }^{19}$ as divorce in the modern sense was unknown. Throughout the marriage, as well as at its dissolution, each spouse under Spanish law maintained separate property interests brought to the marriage or acquired during marriage by gift or inheritance. ${ }^{20}$ In 1840 , Texas community property acquired its strongest protective device with the enactment of the community presumption: ${ }^{21}$ If it is established that an asset was acquired during marriage or was possessed by a spouse on dissolution of the marriage, a spouse or a spouse's heir claiming a separate interest must prove it. ${ }^{22}$ A spouse seeking recovery for a separate contribution to the marriage or a community contribution to a separate asset of the other spouse must assert a claim for reimbursement in the partition of common assets after marital dissolution. ${ }^{23}$

The Spanish matrimonial property law had been in effect in Louisiana since 1769 and was codified in the Louisiana Digest of 1808 and recodified in the Civil Code of $1825 .^{24}$ Among the Anglo-Americans settling in Texas in the 1820s and 1830s, some from Louisiana had legal training or had Louisiana law books. These and other lawyers who settled in provincial Texas seem to have concluded that the civil law of Louisiana and that of Mexico were essentially the same, and in most matters of concern to them, they were correct. During the period of colonization under Mexican rule, the Anglo-American newcomers became familiar with the Spanish matrimonial property system as it was transmitted in terms of Louisiana law. The system was appealing insofar as it empowered the wife to become co-owner of wealth acquired during marriage and comported

18. See FUERO REAL III.3.1-3 (1255). Law 1 gave a general definition of common property of spouses, each of whom was entitled to half of the gains of marriage. Law 2 defined earnings of the marital partners as constituting their common property, and gifts and inheritances as separate property. Law 3 stated that the fruits of separate property were common property. These laws were perpetuated as NuEVA RECOPILACIÓN V.9.2-4 (1567); Novísima RECOPILACIÓN X.4.1-3 (1805).

19. See JuAn de Matienço, CommentaRia in LibRum Quintum Recollectionis legum HISPANIAE on RECOP. V.9.2, gloss 3, no. 18 (1580).

20. Id. on RECOP. V.9.3, gloss 6, no. 1. See also id. on ReCOP. V.9.2, gloss 3, no. 10.

21. See 1839-1840 Tex. Gen. Laws 6, \& 12, reprinted in 2 GAMMEL, supra note 5, at 180 . Its Spanish antecedents were LEYES DE ESTILO 23, RECOP. V.9.1, and NOV. REC. X.4.4.

22. MATIENÇO, supra note 19, at V.9.1, gloss 2, no. 1.

23. See antonio A yerve de Ayora, Tractatus de Partitionibus, Bonorum Communium INTER MARIUM ET UXOREM ET FILIOS AC HAEREDES EORUM I.10.2 (1586); FUERO REAL, supra note 18, at III.4.9.

24. 1808 LA. Dig. III.5.1-98, at 322-45; LA. CIV. CODE arts. 2305-2410 (1825). When the Digest was enacted in 1808, the Spanish law had been in effect in Louisiana for almost 40 years. See BIBIANO TORRES RAMf́REZ, ALEJANDRO O'REILLY EN LAS INDIES 115-18 (1969); 2 FRANCOIS XAVIER MARTIN, THE HISTORY OF LOUISIANA FROM THE EARLIEST PERIOD 14 (1829). 
with the realities of frontier conditions under which both spouses stood together against natural and human forces. ${ }^{25}$

Despite their familiarity with this Hispanic doctrine, the politically dominant Anglo-Americans had casually established the Anglo-American law of dower in January of $1839 .{ }^{26}$ In January of the following year, however, the Congress of the Republic of Texas repealed the law of dower ${ }^{27}$ and enacted a regime of marital sharing in the same act by which the English common law replaced most existing Spanish legal institutions. ${ }^{28}$ The scheme as initially adopted did not carefully replicate Hispanic doctrine, however. Texas common property was more broadly defined to consist of all property of the spouses except lands and slaves brought into marriage and those acquired by gift or inheritance during marriage. ${ }^{29}$ Five years later, a convention assembled to draft a constitution for Texas as an American state. John Hemphill promoted a provision to protect the property of married women, ${ }^{30}$ with further protection for the surviving spouse when the common estate was inadequate. A minority of the committee favored a mere direction to the legislature to pass laws for the protection of the rights of married women along the lines of a community property system. The language of compromise that resulted defined the separate estate of married women in the Spanish terms of Louisiana law and left to the legislature the task of formulating a clear definition of common property. ${ }^{31}$

In 1848 , statutes were enacted that defined the separate estate of each spouse along the lines of the constitutional definition of the wife's separate estate. The

25. Cf. Michael J. Vaughn, The Policy of Community Property and Inter-Spousal Transactions, 19 BAYLOR L. REV. 20, 32-33 (1967) (repeating the vivid hypothesis that spousal sharing of marital gains arose among Visigothic tribes because wives fought and worked shoulder to shoulder with their husbands).

26. 1838-1839 Tex. Gen. Laws 149 , $\S 1-8$, reprinted in 2 GAMMEL, supra note 5, at 149-51.

27. 1839-1840 Tex. Gen. Laws 172 , 1 , reprinted in 2 GAMMEL, supra note 5, at 172; McKnight, supra note 9 , at 120 .

28. 1839-1840 Tex. Gen. Laws 3, $\S 3-4$, at 4, reprinted in 2 GAMMEL, supra note 5, at 177-78.

29. McKnight, supra note 9 , at 120 . The 1840 statute used the phrase "common property" to refer to the spouses' mutual gains during marriage. If it had been fully understood that the Spanish common estate was merely a half-interest in property, much of the later complexity of the system might have been avoided.

30. See William F. Weeks, Debates of the Texas [Constitutional] Convention 486, 504 (1846). The Judiciary Committee of which John Hemphill was chairman proposed the following section:

19. No law shall ever be passed, vesting in the husband, by virtue of the marriage, the separate property of the wife, as now recognized by law, or depriving her of the portion of the common property to which she is now entitled.

The proposed $\S 18$ provided that the legislature authorize "a suitable provision, out of the estate of the deceased wife or husband for the surviving partner where the husband or wife may have died rich, leaving the other in necessitous circumstances ...." Id. at 596.

31. TEX. CONST. OF 1845 , art. VII, $\$ 19$ provides that:

All property, both real and personal, of the wife, owned or claimed by her before marriage, and that acquired afterward by gift, devise or descent, shall be her separate property; and laws shall be passed more clearly defining the rights of the wife, in relation as well to her separate property, as that held in common with her husband.

The 1876 Constitution maintained the same text. TEX. ConST. OF 1876, art. XVI, $\& 15$. See also McKnight, supra note 9, at 123. 
common property was defined as the rest of their acquisitions during marriage..$^{32}$ The community was made liable for all of the husband's debts and those of the wife contracted during marriage for necessaries. ${ }^{33}$ The husband was given control of the common estate, and (in a lapse into English legal ideology) the separate estate of the wife was put under the husband's management as well. ${ }^{34}$ Thus the control of the spouses' property in Texas generally replicated that of Anglo-America prior to reform, though ownership was significantly different. Because the Texas wife retained the Hispanic right of will-making, ${ }^{35}$ she could dispose of her half-share of the common property.

After enacting a further statute to regulate the payment of marital debts against a deceased spouse's estate ${ }^{36}$ the legislature left the elaboration of the system to the courts as responses to particular disputes demanded. In the course of judicial development, the decisions of the Texas Supreme Court achieved a fortuitous blend of Anglo-American and Hispanic principles of marital property law.

Most significantly, the Texas courts embraced the Anglo-American principle of tracing, by which separate property might maintain its identity through mutation. The tracing principle was first enunciated in Love v. Robertson, ${ }^{37}$ an 1851 case involving a slave purchased during marriage with both community funds and a husband's separate funds. The court held that ownership resulted in proportion to the amount of the total price paid with each type of funds. The decision thereby reduced the breadth of the marital community in Texas. ${ }^{38}$ By relying on the equitable tracing doctrine, the court achieved a result more consistent with English law, which sought to preserve sole ownership whenever

32. 1847-1848 Tex. Gen. Laws 77, $\$ 3$, at 78, reprinted in 3 GAMMEL, supra note 5, at 77-78. The community presumption was not restated but was still in effect from the 1840 enactment. 1839-1840 Tex. Gen. Laws 3, $\S 12$, at 6, reprinted in 2 GAMMEL, supra note 5, at 177 .

33. 1847-1848 Tex. Gen. Laws $77, \S 3$, at 78, reprinted in 3 GAMMEL, supra note 5, at 77-78. The wife was thus acting as the husband's agent of necessity. She had no independent contractual power at that time.

34. 1847-1848 Tex. Gen. Laws 77, \$2, at 78, reprinted in 3 GAMMEL, supra note 5, at 77.

35. 1839-1840 Tex. Gen. Laws 167, $\$ 1$, reprinted in 2 GAMMEL, supra note 5, at 341.

36. 1856 Tex. Gen. Laws 51, $\$ 1-9$, reprinted in 4 GAMMEL, supra note 5, at 469-71.

37. Love v. Robertson, 7 Tex. 6 (1851).

38. No overt anti-community bias appears in the Love opinion, however. The court nevertheless found the question difficult. It is apparent that neither the court nor counsel had access to Spanish materials that would have disclosed the historic solution. According to the case reporter's summary of the briefs, the only Spanish authority cited by the losing party was White's Recopilacion. JOSEPH M. WhITE, A NeW COllection OF LAWS, CHARTERS, AND LOCAl ORdINANCES OF THE GOVERNMENTS OF GREAT BRITAIN, FRANCE AND SPAIN, RELATING TO CONCESSIONS OF LAND IN THEIR RESPECTIVE COLONIES TOGETHER WITH THE LAWS OF MEXICO AND TEXAS ON THE SAME SuBJECT (1839) (reprinting IGNACIO JORDAN DE ASSO Y DEL RIO \& MIGUEL DE MANUEL RODRÍGUEZ, INSTITUCIONES DEL DeRECHO DE CASTILlA (6th ed. 1805) (Lewis F.C. Johnston, trans.)). The pages dealing with community property law are reproduced in MCKNIGHT \& REPPY, supra note 11, at 6-8. In Love, prevailing counsel cited a Louisiana decision, which the court said was not on point, to the effect that when a husband managing the wife's separate property sold an asset and reinvested the proceeds in other property, the rule of tracing applied. The attorney's primary point was that the statute defining the husband's separate property as including property owned before marriage would be eviscerated by rejecting the tracing principle. Ultimately the court simply declared that "[e]quity and justice" required acceptance of the tracing rule. 
possible. The Spanish law would have held that the acquisition during marriage was community even if made entirely with the husband's separate property. Spanish law recognized a very narrow application of the tracing principle, confined to exchanges of landed patrimony or immediate reinvestment of proceeds from its sale; the principle of reimbursement was relied on to compensate the separate estate in other situations. ${ }^{39}$ The Texas Supreme Court, however, followed the Anglo-American solution to establish the doctrine of tracing separate property through changes in form in order to preserve its character as separate. Love is the first of many Texas Supreme Court cases favoring separate property ownership over a community claim when there is no clear statutory answer.

A similar fusion of disparate principles was achieved in relation to interspousal gifts. Along Anglo-American lines, ${ }^{40}$ a presumption of gift was indulged when the husband bought property with his separate estate in his wife's name and when he made a transfer to his wife of his separate estate or property held in common. ${ }^{41}$ These were instances when Hispanic legal norms were very different from those of Anglo-America. In an effort to protect heirs who were beneficiaries of the Spanish doctrine of forced heirship, Spanish law was hostile to all interspousal gifts. ${ }^{42}$ But in the case of alleged donative transfers, the Texas court did not mention the Hispanic tradition, either because of lack of awareness or because Texas had abolished the doctrine of forced heirship in 1856 , when the first dispute of that kind came before the court. In the case of a husband's purchase of property with community funds in the name of his wife, however, the court entertained no presumption of gift and required proof of donative intent, ${ }^{43}$ as under Spanish law. Some shrinking of the breadth of the Texas marital community, therefore, resulted from application of the presumption of gift in cases of a community transfer (as distinguised from purchase). In judicial decisions concerning sales of property of a deceased wife when the property was held in her husband's name, however, the court favored the bona fide purchaser as against her heirs. ${ }^{44}$ In this instance, as in the tracing decisions, the Texas court was, without any conscious reflection on the broad consequences of the decisions reached (and usually without making any conscious choice between Anglo-American and Spanish solutions), applying equitable commercial standards to the subject matter of Spanish marital property law, which had usually subsisted outside the mainstream of commerce.

39. LeYes de Estilo 203 (1310), ReCop. V.9.1 (1567), Nov. ReC. X.4.4 (1805). See MATIEnço, supra note 19, at gloss 2, nos. 4-5; 2 JOSEF FEBRERO, LIBRERIA DE EsCRIBANOS (FEBRERO MEJICANO) II.10.7 (1834).

40. See 5 William F. Fratcher, SCOTt ON Trusts $\$ 442$ (1989).

41. Story v. Marshall, 24 Tex. 306 (1859); Smith v. Strahan, 16 Tex. 314 (1856).

42. See SIETE PARTIDAS IV.11.4-5 (1256). A gift to a spouse (or to anyone else) effectively reduced the estate that Spanish law preserved for heirs.

43. Higgins v. Johnson's Heirs, 20 Tex. 389 (1857).

44. Patty v. Middleton, 17 S.W. 909 (Tex. 1891); Cooke v. Bremond, 27 Tex. 457 (1864). 
The Texas Supreme Court was, nevertheless, sufficiently imbued with Louisiana's Hispanic tradition of family property law that in 1859 it maintained the Hispanic rule characterizing income from separate property as community. ${ }^{45}$ Although the California Supreme Court almost simultaneously adopted the Anglo-American approach of attributing income from separate property to the separate estate of the owner, ${ }^{46}$ the Texas court followed the traditional Hispanic path. ${ }^{47}$ The court did not rely on the constitutional provision, however, but on "[t]he principle that lies at the foundation of the whole system of community property ... that whatever is acquired by the joint efforts of the husband and wife, shall be their common property." 48 These contrasting developments are more remarkable when the statutes defining community property then in force in both states are considered. Texas's statute lent itself to the interpretation that income from separate property was separate, ${ }^{49}$ whereas the California statute-held invalid there on the ground that the state constitution protected "separate property" as understood in Anglo-American law-clearly provided that such income was community. Texas's adherence in 1859 to the old Spanish rule was thus conservative, but the result was nonetheless progressive in the sense that on her husband's death the full range of profits of marriage were evenly divided. ${ }^{50}$ It was a time when divorce was very rare.

When the Texas Supreme Court finally focused on the concept of reimbursement in a dispute involving community benefits rendered to a separate estate during marriage, it recognized this principle also in Hispanic terms. ${ }^{51}$ Because the same rule measured reimbursement in cases where a separate estate made a claim based on improvement of the community (for example, paying for construction of a house on community land) as when the community estate made the claim based on improvement contributed to separate property, the general rule chosen cannot be viewed as favoring the community over the separate estate. $^{52}$ But for the measure of recovery, the conclusion was the Hispanic norm of cost without any apparent consideration of analogous Anglo-American standards. ${ }^{53}$

45. De Blane v. Hugh Lynch \& Co., 23 Tex. 25 (1859).

46. George v. Ransom, 15 Cal. 322, 332-33 (1860).

47. De Blane, 23 Tex. at 29.

48. Id. at 29.

49. It included in a spouse's separate estate the "increase" of his or her separate property. 18471848 Tex. Gen. Laws $77, \$ 2$, reprinted in 3 GAMMEL, supra note 5, at 77 .

50. By 1859 a number of common law states, including nearby Arkansas and Mississippi, had adopted matrimonial property regimes, which in some measure defined a wife's premarital property and its income like that of an unmarried woman. See infra note 68. But the Anglo-American widow's rights were little improved.

51. Rice v. Rice, 21 Tex. 58, 66-67 (1858) (an unusual case in which the husband sought a divorce on the ground that his wife had continually beaten him); Furrh v. Winston, 1 S.W. 527 (Tex. 1886). In each case a building had been constructed at community expense on the separate land of one spouse.

52. The improving estate obtained no share of title and was entitled to be reimbursed for the cost of the improvement (funds spent and valaue of community labor).

53. The prevailing Anglo-American rule was that a cotenant who had improved the cotenancy was entitled to compensation for enhancement in the value of the property only upon partition of the cotenancy. See A.C. Freeman, CotenanCY AND PARTITION $\S 510$, at 680 (2d ed. 1886); Annotation, 
Perhaps because of the mechanical ease with which the rule was applied, after some vacillation the Texas court adhered ${ }^{54}$ to the Spanish inception of title principle in distinguishing between property interests brought into marriage (and thus separate) and those acquired during marriage, which are shared. ${ }^{55}$ Hence, if a property right was rooted in a contract that antedated the marriage, the property interest that might mature during marriage was a separate interest. Unlike most other community property states, ${ }^{56}$ Texas has continued to apply this principle broadly - as, for example, to the characterization of proceeds of a life insurance contract entered into before marriage but kept in force with community premium payments during marriage. ${ }^{57}$ Because the Spanish principle of reimbursement allows the community to recover the amount paid in making premium payments for a separate insurance policy bought before marriage, the community does not share in the enhanced value of the whole life policy, which is the only type to which Texas courts have ever directed their attention. Thus, by preventing the community from becoming co-owner of a spouse's separate premarital acquisitions, the Texas court allowed modest shrinkage of the possible breadth of community assets but did so in accordance with Hispanic antecedents. ${ }^{58}$

Adjustment on Partition of Improvements Made by Tenant in Common, 1 A.L.R. 1189, 1202-03 (1919). Because enhancement was the measure of Anglo-American compensation, cost of improvement was rarely mentioned in the cases. In the course of a business cotenancy to which most Anglo-American cases were devoted, wasting repairs (such as replacement of a roof) would ordinarily have been made by agreement of the cotenants and paid for out of rents. The cost of an uncompensated improvement that produced enhancement valued at less than cost rarely suggested judicial comment.

54. See Welder v. Lambert, 44 S.W. 281, 283-87 (Tex. 1898).

55. See Alfonso de AZEvedo, Comentariorum IURIS Civilis in Hispaniae Regias CONSTITUTIONES On RECOP. V.9.2, no. 16 (1594); 1 JOSEF FEBRERO, LIBRERÍA DE ESCRIBANOS: JUICIOS I.4.1.23 (3d ed. 1786).

56. See REPPY \& SAMUEL, supra note 16, at 6-1 through 6-15.

57. McCurdy v. McCurdy, 372 S.W.2d 381, 383-84 (Tex. Civ. App.-Waco 1963, writ refd). At this time, in California and most other community property states the solution to the problem in McCurdy was ownership shared pro rata. Thus, if at the time of characterization of the policy or proceeds the husband's separate estate had paid $\$ 5,000$ in premiums before marriage and the community thereafter paid $\$ 15,000$, the asset was one-fourth separate and three-fourths community. See Modern Woodmen of America v. Gray, 299 P. 754 (Cal. Dist. Ct. App. 1931). The most recent California decisions dealing with term life insurance policies classify the policy or proceeds based on the nature of the most recent premium paid. But see Estate of Logan, 236 Cal. Rptr. 368 (Cal. Ct. App. 1987) (stating that prior payments should be credited if the insured had become uninsurable so that such payments were significant in purchasing the right of reinsurance).

58. Unlike a Texas life insurance policy acquired before marriage-and thus an entire separate interest (subject to a community right of reimbursement for payment of premiums)-Texas courts have treated an employee pension plan acquired before marriage as owned pro rata by the separate and community estates in proportion to the employee's periods of employment when single and married. Taggart v. Taggart, 552 S.W.2d 422 (Tex. 1977); Cearley v. Cearley, 544 S.W.2d 661 (Tex. 1976); Busby v. Busby, 457 S.W.2d 551 (Tex. 1970).

The character of proceeds of a separate life insurance policy may be effectively altered by applying the new measure of reimbursement for improvement to realty. See infra note 136 and accompanying text. By applying the new standard of reimbursement to a separate life insurance policy (not subject to decrease in value unless the insurance company fails), its value will be enhanced as a result of payment of premiums with community property, and the community will be entitled to reimbursement for the enhanced value, not merely for premiums paid. Thus, when the insured spouse dies, the proceeds of the policy will be apportioned in a manner similar to that applicable to retirement benefits. On divorce, the 
Perhaps the most remarkable consequence of blending of Anglo-American and Hispanic concepts produced, and in turn resulted from, legislation concerning succession to property at death. The Anglo-American inclination to keep ownership of property within the blood line of the decedent was evident in the Texas statutes on intestate succession to separate property, which followed the pattern of English law in favoring the decedent's heirs with a mere life estate of one-third in favor of the surviving spouse. ${ }^{59}$ An independent provision was made for succession to community property, and here the Anglo-American inclination to avoid cotenancy is evident, to the detriment of collateral heirs. Because one-half of the common estate belonged to a surviving spouse, all of the deceased spouse's half passed to lineal heirs, and in their absence the decedent's half was reunited with the other half in the hands of the surviving spouse. ${ }^{60}$ This difference in rules of succession produced a notion of separate and community interests as different types of property; this disparity was accentuated by the lawyers' habit of referring to "the separate estate" and "the community estate." For the Spanish lawyer, the difference had merely been that of a particular spouse's owning a separate whole interest or a common half interest. Anglo-Texans, however, thought of the two interests as different types of property, and the peculiar word "community," derived from the French communauté used in Louisiana, fortified this difference. ${ }^{61}$

By the last quarter of the nineteenth century, Texas courts-with rare exception $^{62}$-no longer looked to Louisiana or Spanish sources for guidance in

community will (in effect) have a pro rata share of the cash surrender value of the policy, subject to equitable division.

59. 1839-1840 Tex. Gen. Laws 132, \&10, at 134, reprinted in 2 GAMMEL, supra note 5, at 306, 308; 1847-1848 Tex. Gen. Laws 129, $\$ 4$, at 130-31, reprinted in 3 GAMMEL, supra note 5, at 129, 130-31.

The life estate in the wife with a remainder to the decedent's heirs also produced eventual unified ownership in cases when the heir was a single child. The alternative mode of intestate succession might have given an undivided half interest to the widow (who could then devise her half to anyone) and an undivided half interest to the child who was sole heir. Intestate succession involved creation of a cotenancy when more than one child (or other issue) were heirs, because Anglo-American jurisdiction had abolished primogeniture by 1800 . See Richard B. Morris, Primogeniture and Entailed Estates in America, 27 COLUM. L. REv. 24, 25, 51 (1927); Carole Shammas, English Inheritance Law and Its Transfer to the Colonies, 31 AM. J. LEGAL HIST. 145, 154 (1987).

60. 1839-1840 Tex. Gen. Laws 3, § 4, at 4, reprinted in 2 GAMMEL, supra note 5, at 177, 178 (1898); 1847-1848 Tex. Gen. Laws $77, \S 3$, at 78, reprinted in 3 GAMMEL, supra note 5 , at 77,78 .

61. 1825 LA. CIV. CODE art. 2371, in effect when Texans began to use the term "community" property, begins "This partnership or community consists of all the profits of all the effects of which the husband has the administration ...." ("Cette société ou communauté se compose des fruits de tous les biens dont le mari a l'administration...."). In Spanish the term for community property is bienes ganaciales. See JoAQuín Escriche Y MARTIN, DiccionaRIo DE LEgISLACIÓN CIVIL, PENAL, COMERCIAL Y FORENSE 71 (1st ed. 1831). The Texas Constitution and earliest statutes referred to "common" property, not community. The term "community" appears one time in Hemphill's opinion in the first significant Texas marital property case in 1843, Scott \& Solomon v. Maynard, Dallam 548, which repeatedly uses the word "common." Regular use of "community" rather than "common" seems not to begin until Wood v. Wheeler, 7 Tex. 13 (1851).

62. For some instances in which the Texas court continued to look to Louisiana Law, see Richardson v. Hutchins, 3 S.W. 276 (Tex. 1887); Welder v. Lambert, 44 S.W. 281 (Tex. 1898). 
matters of matrimonial property. ${ }^{63}$ To say that a distinctly Texas system had developed would be an exaggeration, however, because there were still many gaps of undefined doctrine. Divorce was not sufficiently prevalent to have presented many problems for judicial solution, and therefore most matrimonial problems before the courts arose in the context of debt-collection and succession. Elements of Anglo-American law had been applied to some aspects of the system, but despite some departures, Texas law maintained the principal features of the Hispanic model.

Departing from old Spanish authority ${ }^{64}$ (which does not seem to have been consulted) the Texas Supreme Court of the late nineteenth century also produced a body of authority ${ }^{65}$ that evidenced a marked hostility to spousal agreements (marital as well as premarital) that sought to alter the statutory community regime. Though not consistent in its reasoning, the court tended to be guided by the statutory prohibition of premarital agreements to alter the order of descent. ${ }^{66}$ In 1902 this conclusion was, in effect, generalized to bar agreements to change the character of separate property to community, ${ }^{67}$ though the court did not rely on the earlier line of authority. The Texas Constitution was not mentioned.

\section{III}

\section{Stage II: The WayWARd PROCESS OF REFORM, 1911-1967}

The reform of Texas matrimonial property law in the second and third decades of the twentieth century was the long delayed completion of the movement to expand the property rights of married women ${ }^{68}$ that was initiated by the perpetuation of the community property system in 1840 . As adherents to a minority marital property system, the community property states were cut off from the mainstream of American property law reform. Each community property state was further isolated by the peculiar details of its own system. In

63. Nor did the courts of Texas and those of the western community property states often look to each other.

64. Under old Hispanic law, spouses could, prior to marriage, formally contract for a marital property regime different from that set forth in the codes and other sources of law. Old Spanish law also allowed spousal agreements during marriage to alter the marital regime. MATIENÇO, supra note 19, at gloss 1, no. 60; on Recop V.9.9, gloss 1, nos. 2,5. But there were serious doubts that such alterations affected the rights of heirs and creditors. See 2 SANCHO Llamas Y Molina, Comentario Crftico, JURIDICO, LITERAL, A LAS OCHENTA Y TRES LEYES DE TORO 314 (3d ed. 1853).

65. Proetzel v. Schroeder, 19 S.W. 292 (Tex. 1892) (marital agreement); Groesbeck v. Groesbeck, 14 S.W. 792 (Tex. 1890) (marital agreement); Green v. Ferguson, 62 Tex. 525 (1884) (formal premarital agreement revoked by marital agreement); Cox v. Miller, 54 Tex. 16 (1880) (marital agreement); Wallace v. Finberg, 46 Tex. 35 (1876) (informal marital agreement).

66. $1839-1840$ Tex. Gen. Laws 3, $\S 5$, at 5, reprinted in 2 GAMMEL, supra note 5, at 177, 179.

67. Kellett v. Trice, 66 S.W. 51 (Tex. 1902) (marital agreement).

68. It was certainly a delayed reaction. The first married women's property acts appeared in Arkansas in 1835 and Mississippi in 1839. This type of reform, giving the wife most of the property rights and contractual powers that were ordinarily provided in an Anglo-American premarital settlement of the early nineteenth century, was adopted in New York in 1848. See WILLIAM A. REPPY, JR., COMMUNITY PROPERTY IN CALIFORNIA 2 (2d ed. 1988). 
the case of Texas, isolation was made more pronounced by the state of development that the system had reached by the early twentieth century. Texas, like some of the other community property states, was slow to see the need for reform because of the locally generated myth of the great liberality of her system toward married women.

In Texas the drive for equality in rights to property was closely associated with the women's suffrage movement. ${ }^{69}$ The first fruit of this effort in Texas was enacted in 1911: a statute permitting a married woman to petition for judicial removal of the disabilities of coverture for business purposes and to acquire full contractual power in that context. ${ }^{70}$ By that time, such "sole trader" statutes were not a novelty in common law marital property states and some community property states. ${ }^{71}$ Even though the husband's consent was required in the Texas process, ${ }^{72}$ the statute represented a considerable advance in married women's rights.

Allowing married women to conduct their own businesses within the community property system suggested shifting a part of the management of the community property to them. The 1911 sole trader law, thus, seems to have provided the impetus for broad marital property law reform as well as its course.

In 1913, an act entitled "Husband and Wife-Defining Separate and Community Property"73 gave wives control of their earnings and the profits from their separate estates. ${ }^{74}$ There were limitations, but the husband's sole control of the community estate was broken. Instead of a single marital partnership with the husband as managing partner, two partnerships emerged if the wife had property of her own or produced earnings: The wife became the managing partner of the second partnership, which consisted of the income from her separate property and her earnings. To "protect" the married woman from the imposition of third persons, the 1913 Act required the husband's joinder for disposition of community lands or securities she managed, ${ }^{75}$ but her manage-

69. The two related movements sought and achieved their objectives almost simultaneously. Jane Y. McCallum, Woman Suffrage, in 2 WALTER PRESCOTT WEBB, THE HANDBOOK OF TEXAS 928 (1952). See McKnight, supra note 9, at $124 \mathrm{n.44}$ and accompanying text.

70. 1911 Tex. Gen. Laws $92, \S \S 1-4$. Section 4 gave the wife as a feme sole full contractual capacity and declared her separate property liable for the debts incurred in her business. The statute did not classify her earnings in such a business as separate property and did not say that they were liable for her debts as community property. Potential lenders could not have relied on being able to reach community property in the feme sole's business even though the loan was taken out to expand the business. The poorly drafted sole trader law was finally repealed by 1969 Tex. Gen. Laws 2707 , \& 6 at 2733 . See McKnight, supra note 9, at 124.

71. For example, California had very soon after statehood enacted laws permitting wives to qualify as sole traders. 1852 Cal. Stat. 101. Unlike Texas, California made the earnings of a feme sole her separate property.

72. McKnight, supra note 9, at 124 .

73. 1913 Tex. Gen. Laws $61, \$ 1$ at 61-62. See William O. Huie, Commentary on the Community Property Law of Texas, 13 VERnON's TEX. REV. CIV. STAT. 1, $39-40$ (1960).

74. McKnight, supra note 9 , at 125 .

75. Prior to the 1913 legislation, the husband was the manager of all the community estate though the wife was required to join in conveyances of the homestead, and the husband managed the wife's separate property, subject to her joinder in conveyances. Under the 1917 legislation (supra note 2), the 
ment powers over a part of the community were assured, and that part committed to the wife's control was protected from her husband's creditors. 'The fundamental partnership principle of Texas community property law was nonetheless maintained. Indeed, it was expanded by giving wives some management power, whereas previously their participation in the marital partnership had been confined to co-ownership.

The most significant impediment to the married woman's exercise of proprietary rights was her lack of full contractual power. ${ }^{76}$ As proposed and initially enacted, the 1913 statute had given full contractual capacity to married women, but in response to Governor Colquitt's objection, ${ }^{77}$ the bill was recalled and the provision was deleted. The law as passed had considerably less impact on Texas spouses and their business practices than if the original provision had been included.

Other reforms were enacted to enhance the property rights of Texas married women at almost every regular legislative session from 1913 until 1923. In 1915 a married woman's recovery for personal injury was statutorily characterized as her separate property. ${ }^{78}$ In 1917 a much broader reform was enacted. Texas followed the plan of California and the other western community property states (except Idaho) ${ }^{79}$ in defining the income from both spouses' separate property as belonging wholly to its owner. ${ }^{80}$ In a decade Texas law had been radically, though not systematically, transformed. Most significantly, the unity of the marital partnership had not been maintained.

husband was also required to join in conveyances and encumbrances of the wife's separate lands and securities. In the case of both separate and community assets, a court could waive the husband's refusal to join upon finding that the transaction the wife wished to enter into was in her best interest.

76. A married woman who had complied with the sole trader statute could bind her separate estate by her contracts. See 1911 Tex. Gen. Laws 92, $\$ \$ 1-4$. Her contracts did not bind her interest in the community estate under that act, however. But the wife had broad contractual powers under the 1913 act, subject to certain limitations. See supra note 75. See also Cauble v. Beaver-Electra Refining Co., 274 S.W. 120, 121-22 (Tex. 1925); Gohlman, Lester \& Co. v. Whittle, 273 S.W. 808 (Tex. 1925); Whitney Hardware Co. v. McMahan, 231 S.W. 694, 695-96 (Tex. 1921).

77. See Red River Nat'l Bank v. Ferguson, 206 S.W. 923, 926 (Tex. 1918), for a summary of the legislative history of the 1913 act.

78. 1915 Tex. Gen. Laws 103, § 1; McKnight, supra note 9, at 125 . Previously, all personal injury recovery obtained on behalf of either spouse had been characterized as community property. That purported application of the disjunctive syllogism has been described (with roughly equal clarity) as giving community property a "waste basket" definition. Marriage of Parsons, 622 P.2d 415, 416 (Wash. Ct. App. 1981), overruled by Marriage of Brown, 675 P.2d 1207, 1213 (Wash. 1984). Such recovery was not property owned before marriage or acquired by succession or gift and thus was community property. See Ezell v. Dodson, 60 Tex. 331 (1883) (recovery for wife's injuries).

The kind of gender discrimination in this and several other reforms discussed here could be attacked today as violative of the Equal Protection Clause of the Fourteenth Amendment to the federal Constitution (not to mention the Texas Equal Rights Amendment of 1972, see infra note 102). It was not until 1971 that the United States Supreme Court held that gender discrimination denied equal protection. Reed v. Reed, 404 U.S. 71 (1971). Legislation intended to correct for prior discrimination against women has also been upheld. Kahn v. Shevin, 416 U.S. 351 (1974).

79. See GeORge MCKAy, A TREATISE ON THE LAW OF COMMUNITY PROPERTY $\S 286$, at 208 (2d ed. 1925).

80. McKnight, supra note 9, at 125 (citing 1917 Tex. Gen. Laws 436, § 1). An amendment of 1921 dealt with liability of separate property. 1921 Tex. Gen. Laws $251, \S 1$. 
Just after the legislature had adopted its general consolidation of family property law in 1925 (by which the wife's control of her earnings had been omitted by apparent oversight), the Texas Supreme Court considered three cases $^{81}$ dealing with the right of a husband's creditor to be satisfied from the rents and profits from the wife's separate property, redefined in 1917 as her separate property not subject to the husband's debts. Evidently troubled by the speed and extent of reform of married women's property rights, the court resorted to the constitutional provision to restore, as far as it could, its perception of the proper role of married women in Texas property law. In nullifying the 1917 reform, which made income from separate property separate, the court held that the constitutional provision on marital property was the sole source of the definition of that estate. By necessary implication, the constitution thus required that any property not specifically defined as separate property was community. ${ }^{82}$

Although the court chose to rely wholly on Texas sources (the supposed definition supplied by the constitution and legislative recognition of that fixed doctrine), the Hispanic tradition went unmentioned, but it is evident that legislative custom and judicial decision had continued to rest on that tradition. ${ }^{83}$ The court noted that the Texas legislature had the power to alter the rules of management and liability of community property but not the fundamental definitions that had been fixed by legislative acquiescence. For the first time-eighty years after the constitutional provision on marital property had been adopted-the court asserted that the constitution controlled the definitions of community and separate property. That assertion by the court caused a major shift in the analysis of matrimonial property law. In severely fettering both legislative and judicial reform, the court's 1925 decision stands as the most conservative bulwark in the history of Texas matrimonial property law.

A desultory repair of the constitutionally infirm statutes was not undertaken until 1929.84 It was generally assumed thereafter, as the statute continued to provide ${ }^{85}$ that the husband's place as manager of the entire community had been restored. The statute exempting the income from the wife's separate

81. See supra note 1.

82. Arnold v. Leonard, 273 S.W. 799, 804 (Tex. 1925). The statutory provision making the rents and profits of the wife's separate property not liable for her husband's debts was, nevertheless, severable from the unconstitutional provision classifying those rents and profits as her separate property. Hence, the husband's creditors ultimately did not prevail.

83. Id. at 802-03. The California Supreme Court, dealing with the identical constitutional language in 1860 , had reached precisely the opposite result by holding that "separate property" as a common law term of art embraced rents and profits. See supra notes 46-50 and accompanying text. Although unmentioned, the Hispanic tradition was very much stronger in Texas in 1925 than in California in 1860 . See supra note 30 . Until 1980 the Texas Constitution, specifically defined the wife's separate property only and directed the legislature to deal with the "common property."

84. 1929 Tex. Gen. Laws 66, \& 1; McKnight, supra note 9, at 126. The disorderly state of the 1925 statutory revision after the 1925 judicial decisions had been noted by Frank Bobbitt, Is There More Than One Class of Community Property in Texas?, 4 TEx. L. REV. 154, 163 (1926).

85. 1925 TEX. REV. CIV. STAT. art. 4619, \& 1: "during coverture [the common property of the husband and wife] may be disposed of by the husband only . . .." 
property from liability for the husband's debts was nevertheless left intact. This circumstance prompted a most daring move on the part of the Texas Supreme Court: to revive the wife's management of community rents and profits from her separate property despite the 1925 repeal of the statute conferring that power. In 1932 in Hawkins v. Britton State Bank ${ }^{86}$ and later in Bearden v. Knight, ${ }^{87}$ the court so concluded, even though the statutory revision of 1925 had omitted a section specifically stating that a wife had management of the income from her separate estate. ${ }^{88}$

The years of the Great Depression produced little reform of private law and little thought of such reforms. ${ }^{89}$ But social attitudes changed markedly during the war years and the decade that followed to produce demands for legal change. Women had joined the work force in significant numbers, and their participation in business and the professions increased. The first significant reform of the post-war years was, nonetheless, unrelated to women's rights, as such. Instead, it was a reaction to the result of applying the 1925 constitutionalized definition of community property to bar spousal agreements to alter the character of community assets. Obviously, the state legislature cannot waive constitutionally created rights, but citizens ordinarily can. ${ }^{90}$ In 1947 the Texas Supreme Court held that a married couple's physical division of community personalty into equal shares of separate property was constitutionally ineffective. ${ }^{91}$ This 1947 decision precluded Texans from reducing estate taxes owed under a federal act of 1942.92 The only avenue for reform was to change the constitution itself. An amendment was immediately proposed to allow married couples to partition their existing community property into two separate shares. Although the federal tax

86. 52 S.W.2d 243 (Tex. 1932). This was an opinion of the Commission of Appeals adopted by the Texas Supreme Court.

87. 228 S.W.2d 837 (Tex. 1950). This was a decision of the Texas Supreme Court after expansion in 1945 from three to nine members to include the Commission of Appeals. The court overruled First Nat'l Bank of Lewisville v. Davis, 5 S.W.2d 753 (Tex. Comm'n. App. 1928, judgm't adopted). See also Chandler v. Alamo Mfg. Co., 140 S.W.2d 918 (Tex. Civ. App.-Austin 1940, no writ); William O. Huie, Some Principles of Texas Community Property Law, 15 LA. L. REv. 605, 632-37 (1955).

88. In both instances the court inferred the wife's power from her authority to manage her separate property and the husband's lack of power to subject the revenues from her separate lands to liability for his debts. Hawkins, 52 S.W.2d at 245-46; Bearden, 228 S.W.2d at 844.

89. The general broadening of personal property exemptions for family-debtors was a significant exception. See 1935 Tex. Gen. Laws 384, § 1. See also McKnight, supra, note 9, at 126, n.56.

90. See MCKNIGHT \& REPPY, supra note 11, at 19, noting the curiosity of Texas constitutional decisions that allow a citizen to waive the right to jury trial and the right against self incrimination (waivers affecting perhaps years of liberty), but which bar a waiver by a married person of the property rights created in article XVI, $\$ \S 15$ (marital property definition) and 50 (homestead protection).

91. King v. Bruce, 201 S.W.2d 803 (Tex. 1947).

92. The congressional act had included in the estate of the spouse who died first all the community property except that which was shown to be traceable to earnings of the survivor or to income from the survivor's separate property. For many couples there was, therefore, a great advantage in partitioning community property into two shares of separate property (as a tenancy in common or divided shares), especially if they thought that the spouse who was the sole producer of income would die first. See C.M. Hudspeth, Minimizing Federal Estate Taxes in Community Property States, 24 TEX. L. REV. 483 (1946). In 1948 Congress recognized each spouse as a half-owner of the community property for estate tax purposes. See current 26 U.S.C. \& 2033 (1988): "The value of the gross estate shall include the value of all property to the extent of the interest therein of the decedent the time of his death." 
law was changed prior to the 1948 election at which the amendment was presented to the people, ${ }^{93}$ the amendment was nevertheless adopted. ${ }^{94}$

Although the Texas Supreme Court had shown a willingness to repair legislative oversights of 1925 and 1929 , these heroic responses ${ }^{95}$ to prior legislative efforts to give married women a share of the management of the gains of marriage were not consistently maintained. In $1938^{96}$ and again in $1963,{ }^{97}$ contrary conclusions were reached. These inconsistencies and uncertainties of the statutes and their judicial interpretations caused legal academics to discuss a systematic reform of the law, but their voices were rarely heard beyond the law schools. Women's groups complained about the law's injustice toward women, and they began to press for a constitutional amendment to remove gender-based discrimination. All of their grievances were not directed toward marital property law, but within that sphere they objected to the continued dominance of husbands over community property, the need for the husband's joinder in his wife's transfer of her separate land and securities, and the "protective" requirement of a married woman's acknowledgement of her formal transfer of separate property to be taken by an official outside the presence of her husband. An extensive study of the status of married women was therefore mounted in the mid-1950s, but the legislative proposals that emerged from it met with very little success. ${ }^{98}$ Thwarted by legislative intransigence in their efforts to achieve statutory reform, the proponents of change pressed harder for a constitutional amendment to eliminate all gender-based discrimination. ${ }^{99}$ In 1963, the reform movement achieved its first real success with the enactment of legislation granting full contractual capacity to married women and providing them with substantially unfettered control of their separate property. ${ }^{100}$

93. See McKnight, supra note 9, at $126 \mathrm{n} .59$ and accompanying text.

94. The substantive addition to art. XVI, $\S 15$, provided that spouses, without prejudice to pre-existing creditors, may from time to time by written instrument ... partition between themselves in severalty or into equal undivided interests all or any part of their existing community property, or exchange between themselves the community interest of one spouse in any property for the community interest of the other spouse in other community property, whereupon the portion or interest set aside to each spouse shall be and constitute a part of the separate property of such spouse.

95. Hawkins, 52 S.W.2d at 243; Bearden 228 S.W.2d at 837.

96. Strickland v. Wester, 112 S.W.2d 1047 (Tex. 1938) (mutations of wife's earnings were not protected from husband's creditors).

97. Moss v. Gibbs, 370 S.W.2d 452 (Tex. 1963) (following Strickland v. Wester, the court reached the same conclusion).

98. See 1957 Tex. Gen. Laws 1233; Texas Legislative Council, Legal Status OF Married WOMEN IN TEXAS (1956). The 1957 amendment authorized a married woman at least 21 years old to convey separate lands, stocks, and bonds without the consent of her husband if she filed an election with the county clerk "to have sole management, control, and disposition of her separate property."

99. See McKnight, supra note 9, at 127-28.

100. 1963 Tex. Gen. Laws $1189, \$ 6$. The need for a privy acknowledgment of a married woman's transaction was not unequivocally abolished until 1967, however. See Eugene L. Smith, Legislative Note: 1963 Amendments Affecting Married Women's Rights in Texas, 18 Sw. L.J. 70, 72 (1964). In 1965, the law with respect to suits by or against married women was revised, 1965 Tex. Gen. Laws 1010, §§ 1-3, and grounds for divorce were made gender-neutral, 1965 Tex. Gen. Laws 1634, § 1. 
When put to a referendum of the Texas bar, the proposed equal rights amendment failed by a margin of two to one. ${ }^{101}$ Some academic lawyers who were sufficiently aroused by the erratic state of the statutory law had already begun drafting proposals for reform. Feeling a responsibility to follow the expressed view of the bar and sensing the potential dangers of the constitutional amendment, ${ }^{102}$ bar leaders embraced the efforts of the academics as a means of deflecting the amendment. Although the first effort failed for lack of time in the 1965 legislative session, ${ }^{103}$ a more polished measure was passed in 1967 , to be effective on January 1, 1968. ${ }^{104}$ Having thus been thrust into marital property law reform, the organized bar has continued to be the leading player in this field. ${ }^{105}$

\section{CONSTITUTIONAL AND LEGISLATIVE REFORMS HAVE LOOSENED BUT NOT DETACHED JUDICIAL AND LEGISLATIVE TIES FROM OLD TRADITIONS}

Substantial stability in Texas matrimonial property law has been achieved by the fact that almost every successive effort toward statutory reform has been built on the structural base of prior rules. The 1913 revision of the laws drew on

101. See McKnight, supra note 9, at 129.

102. Considerable gender discrimination remained in Texas law, and a chaotic situation would have developed in both civil and criminal matters if an equal rights amendment had been adopted without gender-neutral rules in place or ready to take effect. If, for example, the husband had sole management of the commingled mix of his earnings and his wife's separate property, his control would have been unconstitutional under both the Texas Equal Rights Amendment and the federal Equal Protection Clause as later applied to marital property. Wessely Energy Corp. v. Jennings, 736 S.W.2d 624, 626 (Tex. 1987); Kirchberg v. Feenstra, 450 U.S. 455 (1981). But what was the appropriate solution: equal management, joint management, or management by each of a share of the community estate?

An Equal Rights Amendment (TEX. CoNST. OF 1972, art. I, \& 3a) was finally adopted in 1972 after gender-neutralizing reforms had been legislatively put in place, effective Jan. 1968. 1973 Tex. Gen. Laws LVII.

103. See McKnight, supra note 9, at 130.

104. 1967 Tex. Gen. Laws 735. For a brief summary of these activities, see McKnight, supra note 9 , at $41-42$.

105. After the bar's proposed reform was enacted in 1967, bar leaders responded quickly to criticism of phraseology. For example, TEX. FAM. CODE ANN. $\S 5.22$ (West 1993) was amended, at the bar's urging, in response to the interpretation of the placement of an adjective in Muller v. Evans, 516 S.W.2d 923 (Tex. 1974).

Once it became apparent that personal liability of spouses had not been specifically addressed in the code, the legislature passed appropriate amendments at the bar's urging. See Joseph W. McKnight, Commentary on the Texas Family Code, Title 1, 21 TEX. TECH L. REV. 911, 1048 (1990); TEX. FAM. CODE ANN. \$\$ 4.031, 5.61 (West 1993).

Bar leaders have also played major roles in obtaining legislation relating to disposition of property on divorce. The following statutes are also due to their efforts: TEX. FAM. CODE ANN. \$§ 3.63(b) (property acquired while spouses were domiciled elsewhere); 3.631 (spousal agreements for division of property on divorce); 3.632 (interests in insurance policies); 3.633 (retirement benefits); 3.70-.77 (enforcement and clarification of orders); 3.90-3.93 (property not dealt with on divorce); 5.02 (burden of proving separate property ownership; 5.41-5.56 (premarital agreements and marital partitions).

The bar has been less willing to take on the more difficult tasks of resolving its drafting errors carried into the Family Code in the sections concerning joint management and liability of the community for a spouse's torts. See McKnight, supra note 105, at 911, 1077; Joseph W. McKnight, Annual Survey of Texas Law, Family Law, 30 Sw. L.J. 68, 90 (1976); cf. MCKNIGHT \& REPPY, supra note 11, at 184. 
the cumulative judicial experience under nineteenth century statutes as analyzed in the first Texas treatise on marital property, ${ }^{106}$ whose author drafted the legislation. ${ }^{107}$ Apart from two further editions that responded to the 1913 reforms in the first instance ${ }^{108}$ and the effect of judicial assessment of legislative reform in the second, ${ }^{109}$ the scholarly literature was sparse during the interwar period, though some academic training was offered on the subject, and collections of teaching materials were prepared for that purpose. An increase in scholarly writing and teaching books that organized the subject systematically ${ }^{110}$ greatly contributed to the order of subsequent proposals for reform.

As a consequence of the bar's adjustment to the two-partnership community regime, the 1967 reform perpetuated rather than abandoned the concept of a divided community. Gender neutrality was therefore to be achieved by giving sole management of community property to the spouse whose property or efforts generated the gain and giving management of community property not subject to sole management to the spouses jointly. ${ }^{111}$ A minority sentiment among the drafters of the 1967 statute favored community management and liability along the lines of a business partnership, but all those engaged in the project for reform appreciated that a system formulated in terms of past experience was the only plan that could be enacted at the time.

Although the Texas managerial scheme of two partnerships with different spousal managers is unique among American community property systems, ${ }^{112}$ it provides merely the standard system. Spouses are free to fashion a scheme for property management more suitable to their own needs. ${ }^{113}$ In practice, the majority of Texas couples conduct their affairs as a regime that is largely equally controlled, ${ }^{114}$ and thus many of the objectives of a true partnership are realized.

Though the act of 1967, as codified in the Texas Family Code in $1969,{ }^{115}$ did

106. OCIE SPEer, The Law Of MARRIEd WOMEN IN TEXas (1901).

107. Hortense Ward, Shall Women Have Adequate Laws?, 7 TEX. MAG. 239, 241 (1913).

108. OCIE SPEer, THE LAw OF Marital Rights in TeXas (1916).

109. Id.

110. The most significant of these were William O. HuIE, TEXas Cases and MATERIals ON THE Law of Marital Rights (1955) and its sequel, William O. Huie, Texas Cases and Materials ON THE LAW OF MARITAL PROPERTY RIGHTS (1966).

111. See TeX. Fam. Code ANN. $\$ 5.22$ (West 1993).

112. Some other community property states also allow sole management of certain community assets in particular situations. See REPPY \& SAMUEL, supra note 16, at 14-1 through 14-10.

113. See TeX. FAm. CODE ANN. \&5.43 (1987); LeBlanc v. Waller, 603 S.W.2d 265 (Tex. Civ. App.-Houston [14th Dist.] 1980, no writ) (separating spouses' oral agreement, by which each would have sole management of community property that each possessed, limited the rights of their future creditors).

114. That is, each spouse ordinarily deposits his or her earnings in the same bank account. The result is a jointly managed account subject to their contract of deposit with the bank, which ordinarily provides for equal management in that each spouse can write checks or make withdrawals. With respect to items purchased from the mixed fund, the spouses manage them jointly unless they agree to sole management of items that each buys with funds withdrawn from the mixed account. It may be understood, for example, that the wife can sell or give to charity clothes she has purchased by drawing on the mixed account.

115. The 1969 code lifted the 1967 reforms out of the Revised Civil Statutes with some changes in phraseology not intended as substantive. See, e.g., TEX. FAM. CODE ANN. $\$ 5.22$ (West 1993) (the 
not constitute a complete codification of Texas family property law in the sense that the entire subject was reduced to statutory form, the systematic presentation of the law was far more complete than any prior restatement or revision.

Two sections of the Family Code presented direct challenges to the Supreme Court of Texas to rethink its rigid classification of property as community or separate. One asserted more legislative freedom to classify; the other, more spousal freedom to recharacterize community property as separate property interests. Section 5.01 characterized as a spouse's separate property a recovery of damages in tort for bodily injury to the extent that the recovery does not include compensation for loss of earning power. The constitutional dogma of 1925 would have classified these recoveries as community along with all other acquisitions during marriage not acquired by gift or succession. As early as 1883, the entire recovery had been adjudged community property as a matter of statutory rather than constitutional interpretation. ${ }^{116}$ By shifting the focus of constitutional interpretation from the language of the constitution to its historical roots, the Texas Supreme Court in Graham v. Franco ${ }^{117}$ upheld the new statutory treatment of damages for bodily injury, but the decision did not alter the constitutionalized rules of classification. Thus, the Texas legislature now seems precluded from returning to a rule classifying as community property all aspects of recovery for a spouse's personal injuries during marriage.

The historical approach to constitutional interpretation did not last, however. The notion that article XVI, section 15, rested fundamentally on Hispanic principles was silently put aside six years later in Williams $v$. Williams ${ }^{118}$ when the court returned to its linguistic straightjacket in dealing with interspousal transactions. Williams involved the second statutory challenge in the 1967 reform and the 1969 Family Code. It provided that "persons intending to marry may enter into a marital property agreement as they may desire." 119 In Williams, the

\footnotetext{
management statute).

116. Ezell v. Dodson, 60 Tex. 331 (1883).

117. 488 S.W.2d 390 (Tex. 1972).

118. 569 S.W.2d 867 (Tex. 1978).
}

119. TEX. FAM. CODE ANN. $\$ 5.41$ (West 1993) (emphasis added). In response to the constitutional amendment of 1980 and dissatisfaction with an intermediate statutory change in 1981, this version of the statute was further changed in 1987 by adoption of the Texas Uniform Premarital Agreement Act, of which TEX. FAM. CODE ANN. $\$ 5.43(a)$ (1) (West 1993) carries forward without substantive change the constitutionally questionable invitation to persons planning to marry to make any kind of prenuptial agreement they desire. Section $5.43(a)(7)$ states that such a contract may include a choice-of-law provision concerning the "construction" of the agreement. Silence concerning a choice of law respecting validity seems deliberate. Evidently, a couple cannot go to some other state where freedom of contract principles prevail, execute a prenuptial agreement for a general community (that is, no separate property for either party), specify in the contract that the law of the place of execution will govern, and return to Texas to marry and live with a valid contract. See Maxus Exploration Co. v. Moran Bros., Inc., 817 S.W.2d 50 (Tex. 1991) (contractual rights are determined by the law of the jurisdiction having the most significant contacts with the transaction if the parties have not chosen other governing law); DeSantis v. Wackenhut Corp., 793 S.W.2d 670 (Tex. 1990), cert. denied, 111 S. Ct. 755 (1991) (even if the contracting parties have chosen the law of a particular state to govern their relations generally, Texas law is still properly applied to govern specific matters, such as the validity of a noncompetition clause, if Texas has a materially greater interest in that issue); Robertson v. Estate of McKnight, 609 S.W.2d 534 (Tex. 1980) (applying the most significant contacts rule to characterize interspousal tort recovery between 
parties formally contracted four days before marriage to live separate in property. The marriage was dissolved by the husband's death five months later. In a dispute between the widow and her husband's heirs, the Supreme Court said that

the agreement was void to the extent that income or other property acquired during marriage should be the separate property of the party who earned or whose property produced such income or acquisition. Such provisions were no more than a mere agreement between the parties to establish the character of the property prior to its acquisition during marriage in violation of both the Texas Constitution and the Family Code .... ${ }^{20}$

Graham was not cited. Although old Spanish authority supported prenuptial and spousal contractual alteration of the community marital regime, ${ }^{121}$ that Hispanic tradition had not been as consistently maintained as some commentators have suggested. ${ }^{122}$ Late nineteenth and early twentieth-century Texas authorities severely condemned spousal agreements to alter community property, ${ }^{123}$ and it was generally understood by the Texas legal profession that these decisions reflected Spanish law of the early nineteenth-century. ${ }^{124}$ Thus, the view enunciated in Williams was consistent with nineteenth-century authorities, their supposed Hispanic underpinning, and the rigorous doctrine of constitutional interpretation adopted in $1925 .{ }^{125}$

To abrogate the rule interfering with spousal power to partition community property, another constitutional amendment was necessary. Once again, apparent loss of benefits under federal estate tax law (imposed exclusively on Texas due to the restrictive decisions of her supreme court ${ }^{126}$ ) assisted leaders of the bar in proposing an amendment and in procuring an affirmative vote in favor of reform. ${ }^{127}$

foreign domiciliaries); King v. Bruce, 201 S.W.2d 803 (Tex. 1947) (Texas spouses went to New York and there unsuccessfully attempted a community partition in kind).

120. Williams, 569 S.W.2d at 870 .

121. See supra note 64.

122. See supra note 64. See also William Q. De FuniaK \& Michael J. Vaughn, Principles of COMMUNITY PROPERTY $\$ 59$, at 116 (2d. ed. 1971) (freedom to fashion conventional regime by antenuptial contract a "cardinal precept" of Hispanic law).

123. See supra notes 65,67 and accompanying text.

124. Joseph W. McKnight, Spanish Law for the Protection of Surviving Spouse in North America, 57 A.H.D.E. 365, 389-91 (1987).

125. See Gorman v. Gause, 56 S.W.2d. 855 (Tex. Comm'n App. 1933, judgm't adopted).

126. In Revenue Ruling 75-504, 1975-2 C.B. 363, the Internal Revenue Service took the position that when one spouse made a gift of separate property of his half of the community to the other spouse and the donor died, the gift was in his estate because of a retained interest to receive income therefrom under $\$ 2036$ of the Internal Revenue Code. In Idaho, the donor's intent to give away all interests was respected, but it was assserted that in Texas a donor could not make income of separate capital likewise separate.

127. Although Estate of Wyly v. Comm'r, 610 F.2d 1282, 1290-94 (5th Cir. 1980), decided shortly before the vote of the people to amend the constitution, rejected the position of the Revenue Service, the amendment was nonetheless adopted. 
Late nineteenth-century authorities and the strict doctrine of constitutional interpretation also produced a line of decisions forbidding spousal agreements to create a right of survivorship to community property. The Texas Supreme Court held that a formal spousal undertaking that attempted to convert community funds directly into a joint tenancy was void, and a statute purporting to authorize such an agreement was unconstitutional. To achieve their goal, spouses were required to make two distinct agreements, one changing the community property to a tenancy in common (and thus separate property of each by halves) and a second changing the tenancy in common property to a joint tenancy. ${ }^{128}$ Because neither bankers (who commonly advised them) nor the spouses wishing to achieve survivorship to their community property could seem to master the appropriate procedure for doing so, ${ }^{129}$ a further constitutional amendment was required in 1987 to allow a simpler process. ${ }^{130}$

Although the pace of constitutional change was slow, once the Texas Constitution was amended in 1980 and 1987, the legal air was cleared of much of the dogma generated in 1925. In 1991, the Texas Supreme Court revised its conclusion in Williams $v$. Williams: ${ }^{131}$ The agreement before the court to live separate in property was merely voidable and not void, and thus the invalidity of a similar agreement entered into prior to the 1980 amendment was cured by an implied legislative intent that the amendment should have retrospective effect. ${ }^{132}$ The court (which had been wholly reconstituted since the 1980 amendment) did not comment on the constitutional character of the transaction as a partition but merely referred to it as an agreement between intended spouses to which the law should give effect. There was no intimation of a need to protect the community estate from contractual encroachment.

Some other matters have been more forthrightly treated as public policy decisions both by the court and by the legislature. After examining the reimbursement problem at long intervals and under a variety of economic conditions over a period of more than a century, ${ }^{133}$ the measure of reimbursement was resolutely handled in 1985 with apparent unanimity. ${ }^{134}$ Professional

128. Williams v. McKnight, 402 S.W.2d 505 (Tex. 1966). The apparent reason for the decision was that, under the 1948 constitutional amendment, a spousal partition of community property could create separate property (as constitutionally defined) but somehow, while tenancy-in-common property was separate, an intended joint tenancy was not shown to be so. The statute declared unconstitutional in Williams was passed in response to the Texas Supreme Court's decision in Hilley v. Hilley, 342 S.W.2d 565 (Tex. 1961).

129. A similar case came before the court before amendment was achieved. Maples v. Nimitz, 615 S.W.2d 690 (Tex. 1981). Another case based on facts occurring before the amendment was handled similarly after the amendment was adopted. Allard v. Frech, 754 S.W.2d 111 (Tex. 1988).

130. The amendment provides that "spouses may agree in writing that all or part of their community property becomes the property of the surviving spouse on the death of a spouse." 1987 Tex. Gen. Laws $4114, \S 1$.

131. 569 S.W.2d 867 (Tex. 1978).

132. Beck v. Beck, 814 S.W.2d 745, 749 (Tex. 1991).

133. See Lindsay v. Clayman, 254 S.W.2d 777 (Tex. 1952); Dakan v. Dakan, 83 S.W.2d 620 (Tex. 1935); supra notes 51-53 and accompanying text; see also Joseph W. McKnight, A Retrospective Assessment of Texas Family Property Law Reform, 15 COM. PROP. J. 1, 8 (1988).

134. Anderson v. Gilliland, 684 S.W.2d 673 (Tex. 1985). 
advisers of the legislature had shied away from a statutory solution of the question because of lack of consensus, and the intermediate appellate courts had interpreted the supreme court cases to produce almost every possible conflicting result. After a long period of economic inflation, the view was widely held that limiting reimbursement for improvements to their cost (in the Spanish manner) was unjust. ${ }^{135}$ Following this sentiment, the court concluded that recovery is measured by enhancement in value, whether more or less than cost. ${ }^{136}$ Although the court acknowledged that cost was a far easier standard to apply, the court perceived that the estate providing the benefit was unjustly deprived of its investment in the benefitted estate if recovery is limited to cost during a period of inflation. As a period of economic recession has set in since the court reached its decision, some resistance to the conclusion may be anticipated when enhancement in value is less than cost. Another vice in the court's resolution of the problem is the difficulty of applying the court's rule to cases of reimbursement not involving improvements (as in the case of repayment of a mortgage indebtedness on realty) to which the principle of enhancement is not clearly applicable.

The court has also wrestled with the related problem of reimbursing the community estate for increases in the value of a separate interest in a closely held business entity. ${ }^{137}$ Thus far, the court has dealt with the consequences of inadequate compensation of a spouse employed by a business in which he or she owns a controlling separate interest. ${ }^{138}$ The court has not yet examined the issue of reimbursement for enhancement in value of a separate entity interest attributable to retained earnings when the adequacy of compensation is not at issue. $^{139}$

Such legalistic matters are commonly seen as appropriate for judicial resolution, whereas some broader matters of policy, more easily comprehended by non-lawyers, have been regarded as more appropriate for legislative treatment. One aspect of determining the scope of judicial authority to divide marital property on divorce became so rankling and divisive within the supreme court during the late 1970 s and early 1980 s that the court seemed inclined to leave other related matters to legislative determination.

135. See supra text accompanying notes 51-53. The Spanish commentators of the sixteenth century had also wrestled with the problem of injustice of applying cost as a measure of reimbursement in an inflating economy. See supra note 23.

136. Anderson, 684 S.W.2d at 675.

137. The issue was approached but not reached in McKnight v. McKnight, 543 S.W.2d 863 (Tex. 1976) (a partnership case). See also Vallone v. Vallone, 644 S.W.2d 455 (Tex. 1982) (a corporation coowned by the community and the husband's separate estate).

138. Jensen v. Jensen, 665 S.W.2d 107 (Tex. 1984). Some aspects of the measure of reimbursement may require further attention. See Joseph W. McKnight, Family Law: Husband and Wife, 38 SW. L.J. $131,137-39$ (1984).

139. See Joseph W. McKnight, Reimbursement for Uncompensated Labor Rendered for a CloselyHeld Corporation and Some Other Comments on Jensen v. Jensen, in 3 STATE BAR OF TEXAS, Litigation Section, The Advocate 8, 12-13 (Dec. 1984). 
Borrowing from an 1820 Alabama statute, ${ }^{140}$ the Congress of the Republic of Texas in 1841 laid down two rules from which later Texas law has developed: first, the divorce court might award alimony pendente lite, ${ }^{141}$ and, second, on divorce, the court might divide the parties' estate (with the exception of realty) as it deemed "just and right." 142 The first rule has provided the basis for the conclusion that a divorce court cannot award permanent alimony (that is, support of an ex-spouse after divorce). ${ }^{143}$ This issue of public policy is still debated and has not yet been resolved. The second rule produced the concept of an equitable division of the community estate within the discretion of the trial judge. ${ }^{144}$ The attempt at clarification of this doctrine produced such acute division in the supreme court that the court declined to be drawn into the debate concerning permanent alimony. ${ }^{145}$

Adoption of the principle of equitable division of property on divorce in 1841 put Texas in the forefront of jurisdictions that had continuously adhered to that approach. But the law remained unclear as to the scope of the divorce court's power to divide separate as well as community property. In 1960, the Texas Supreme Court finally decided ${ }^{146}$ that the restriction with respect to division of realty applied only to separate realty, thus allowing division of all community property, as well as separate personalty. In 1969, the professional advisers of the

140. An Act Concerning Divorce, 1820 ALA. GEN. LAws 79, \& 6. The statute empowered a divorce court to "order a division of the estate of the parties" as seemed "just and right." Because Alabama was not a community property jurisdiction, the reference was obviously to the separate property of each spouse.

141. 1840-1841 Tex. Gen. Laws 19, \& 6, reprinted in 2 GAMMEL, supra note 5, at 483-84; TEX. FAM. CODE ANN. \& 3.58(c)(2) (West 1993).

142. 1840-1841 Tex. Gen. Laws 19,84 at 20, reprinted in 2 GAMMEL, supra note 5, at 484; TEX. FAM. CODE ANN. \& 3.63(a) (West 1993) without the exception.

143. See James W. Paulsen, Remember the Alamo[ny]! The Unique Texas Ban on Permanent Alimony and the Development of Community Property Law, 56 LAw \& CONTEMP. ProBs. 7 (Spring 1993).

144. In the early 1980 s, the court twice concluded that marital fault may be considered in dividing community property on divorce even when the ground for divorce is not based on fault. Murff v. Murff, 615 S.W.2d 696 (Tex. 1981); Young v. Young, 609 S.W.2d 758 (Tex. 1980). Although these decisions may be interpreted as constituting an insensitivity to the objective of no-fault divorce, the court's opinion is more accurately viewed as a mere indication of its concern for maintaining the principle of judicial discretion as the most important element in property division. Because most divorces prior to the institution of the broad, no-fault ground (insupportability) in 1969 were consensual (or the consequences of a bargain), insupportability was meant to replace cruelty as the most common ground for divorce and to make the allegation more accurate. The unforeseen, and indeed catastrophic, consequence of the reform was to sweep away the bargaining power of the innocent spouse, thus greatly reducing the potential impact of the court's recent decision making contractual alimony enforceable. See Francis $\mathbf{v}$. Francis, 412 S.W.2d 29 (Tex. 1967).

145. See Eichelberger v. Eichelberger, 582 S.W.2d 395, 402-03 (Tex. 1979). In that instance, due to federal preemption of the classification of assets, there was no significant community estate to divide. The court rejected the suggestion that the court should fabricate an alimony remedy from federal common law. See Northern Group Serv., Inc. v. Auto Owners Ins. Co., 833 F.2d 85, 94 (6th Cir. 1987) (when state law is preempted by federal law, federal common law fills the gap); William A. Reppy, Jr., Learning to Live With Hisquierdo, 6 COM. PROP. J. 5 (1979).

146. Hailey v. Hailey, 331 S.W.2d 299 (Tex. 1960). The court did not look to Alabama law as the legislative source of the Texas act. But the reference to realty in the Alabama statute was clearly to separate property, because Alabama (a common law marital property jurisdiction) had no other kind. 
legislature redrew the statute by omitting the prohibition of division of separate realty but in doing so misadvised the legislature as to their purpose: The legislature was told that the effect of the statute was unchanged. ${ }^{147}$ An issue of statutory construction was therefore presented to the supreme court in 1977. ${ }^{148}$ The court concluded that the legislature had not intended to repeal the bar to division of separate realty ${ }^{149}$ and resorted to the constitution to support its conclusion.

The nature of property is fixed by the Texas Constitution, and not by what is
"just and right."... Section 15, article XVI, of the Texas Constitution declares
that a wife's property, owned or claimed by her before marriage, and that
acquired afterward by gift, devise or descent shall be the separate property of
the wife. By reason of legislation, the husband's property is classified the same
way. If one spouse's separate property may by a divorce decree be changed
from the separate property of the one spouse into the separate property of the
other, there is a type of separate property which is not embraced within the
constitutional definition of the term. ${ }^{150}$

In a grander invocation of the Texas Constitution, the court asserted that a divorce court's award of one spouse's separate property to the other would constitute a governmental taking without a public purpose. ${ }^{151}$ These flights of constitutional rhetoric cannot be taken very seriously. As a merely logical proposition, the court's conclusion with respect to nondivestiture of title to separate realty was nevertheless held to be applicable to separate personalty five years later. ${ }^{152}$

In spite of the asserted constitutional dogma to support the conclusion that separate property cannot be divided on divorce, the court in the later case ${ }^{153}$ also approved new legislation ${ }^{154}$ allowing division of any property earned by spouses while domiciled outside Texas. Thus, in a single decision, the court forbade division on divorce of all constitutionally defined separate property but allowed division of property acquired by non-Texans by means other than gift, succession, and premarital earnings that nonetheless amounted to foreign separate property. It was a remarkable exercise in strict, and very literal, construction. Although the court had been sharply divided in precluding division

147. See Joseph W. McKnight, Commentary on the Texas Family Code, Title 1, 5 TEX. TECH L. REV. 281, 337 (1974).

148. Eggemeyer v. Eggemeyer, 554 S.W.2d 137 (Tex. 1977).

149. Id. at 139.

150. Id. at 140 (footnote omitted). By this same sort of argument, community property undivided on divorce could not become a tenancy in common as concluded in Busby v. Busby, 457 S.W.2d 551 (Tex. 1970).

151. TEX. CONST. OF 1876 art. I, \& 19. An intermediate appellate court thereafter ruled that an unequal division of community property on divorce was unconstitutional. Mendoza v. Mendoza, 621 S.W.2d 420, 423 (Tex. Civ. App.-San Antonio 1981, no writ). But see Rutledge v. Rutledge, 709 S.W.2d 389, reh'g denied, 711 S.W.2d 437, 720 S.W.2d 633, writ ref'd n.r.e., cert. denied, 484 U.S. 848 (1987).

152. Cameron v. Cameron, 641 S.W.2d 210, 219-20 (Tex. 1981).

153. Id.

154. TEX. FAM. CODE $\S 3.63($ b) (enacted in 1981). 
of both separate realty and personalty, ${ }^{155}$ in 1992 a unanimous Texas Supreme Court rejected imposition of a lien on separate realty to insure an equitable division on divorce. ${ }^{156}$

Since 1967, legislative reforms of Texas family property law have responded to decisions of the Texas Supreme Court in only a few instances ${ }^{157}$ and then mainly to correct legislative errors rather than to alter decisions of the highest court unrelated to existing statutes. Judicial decisions that have prompted most legislative acts for doctrinal correction have been those of the trial and intermediate appellate courts. ${ }^{158}$ In $1972^{159}$ and again in $1987,{ }^{160}$ the Texas Supreme Court indicated a relaxed concern for the community presumption in giving some recognition to the presumed intent of a spouse in attempting to withdraw separate funds commingled with community property. Although these cases slightly narrowed the effect of the community presumption, they were not much criticized and provoked no recommendation for legislative change. Rather, it was the inclination of some trial courts to make findings of separate property on insufficient evidence that prompted the statute of $1987^{161}$ to require clear and convincing evidence of separate property. Even so, some considerable doubt about the efficacy of the earlier supreme court holdings must now be entertained.

Several factors have tended to keep law reform within the control of the legislature. Whereas the bar regularly advises the legislature with respect to improvements in family law that it deems advisable, the supreme court is exposed only to a haphazard sampling of potential problems. When one considers that about half of all disputes that make their way to Texas courts involve family matters, the number of matrimonial property cases dealt with by the court in recent decades has been relatively small because of errors presented by other subjects that may seem in greater need of attention. Various other causes have also contributed to this result. Because of the great number and variety of cases presented to the court for review and some lack of continuity in the membership and in interests of the court's members, there has been a disinclination to deal with disputes whose resolution by the intermediate appellate courts seems satisfactory. To these circumstances should be added the statutory limitation imposed between 1892 and 1987 to hear divorce appeals, a

155. Cameron v. Cameron, 641 S.W.2d 210 (Tex. 1982) (personalty); Eggemeyer v. Eggemeyer, 554 S.W.2d 137 (Tex. 1977) (realty).

156. Heggen v. Pemelton, 836 S.W.2d 145 (Tex. 1992). In the interim, the court had declined to extend legislative treatment of foreign separate acquistions on divorce to a case of succession. Estate of Hanau v. Hanau, 730 S.W.2d 663 (Tex. 1987).

157. For example, Muller v. Evans, 516 S.W.2d 923 (Tex. 1974) caused revision of TEX. FAM. CODE $\S 5.22$ (enacted in 1975) (allowing spouses to agree informally to manage their community property otherwise than as statutorily prescribed).

158. The decision in Cockerham v. Cockerham, 527 S.W.2d 162 (Tex. 1975), merely contributed to the confusion that prompted enactment of TEX. FAM. CODE $\$ 4.031$ and the amendment of TEX. FAM. CODE $\$ 5.61$ (enacted in 1987) (clarifying personal liability of one spouse for obligations incurred by the other).

159. McKinley v. McKinley, 496 S.W.2d 540 (Tex. 1973).

160. Hanau, 730 S.W.2d at 667.

161. TEX. FAM. CODE $\$ 5.02$ (enacted in 1987). 
barrier that kept some unusual or novel property disputes ${ }^{162}$ from receiving the court's consideration. Although this limitation persisted from a time when divorces were relatively rare, regarded as socially abhorrent, and in most instances deemed beneath the dignity of the supreme court's consideration, the court used the old statute to justify its decision not to review an ever-increasing number of divorce appeals, which sometimes presented matrimonial property issues of considerable importance. All divorce cases that did not raise issues of constitutional or statutory interpretation or conflicts within the intermediate appellate courts were barred from review until $1987 . .^{163}$

A striking instance of judicial inaction for lack of jurisdiction concerns the definition of a spouse's constructive fraud in making a gift of community property without the other spouse's consent. After widely spaced legislative refusals to deal with the problem in 1840 and $1967^{164}$ and a dismal prediction on the part of the court in $1961^{165}$ that a serviceable definition could not be formulated, the intermediate appellate courts fashioned a seemingly acceptable rule, and the supreme court has merely let it stand. ${ }^{166}$ Without commenting on the issue of constructive fraud, ${ }^{167}$ the Texas Supreme Court then provided an alternative response to the problem (in rare circumstances) by fastening an illconsidered illusory transfer doctrine onto Texas marital property law.

162. See Kellett v. Kellett, 59 S.W. 809 (Tex. 1900); Burguieres v. Farrell, 87 S.W.2d 463 (Tex. 1935); Lloyd v. Bonds, 217 S.W.2d 1000 (Tex. 1949); James P. Hart, The Appellate Jurisdiction of the Supreme Court of Texas, 29 TEX. L. REv. 285, 307-09 (1951). There were few breaks in the barrier. See Bearden v. Knight, 220 S.W.2d 837 (Tex. 1950); Korn v. Korn, 15 S.W.2d 1017 (Tex. Comm. App. 1929), motion to modify judgm't denied, 29 S.W.2d 1075 (Tex. Comm. App. 1930). For cases that the court was statutorily barred from hearing, see Bobbitt v. Bass, 713 S.W.2d 217, 220 (Tex. App.-El Paso 1986, writ dism'd w.o.j.) (character of herd of livestock); Breeze v. Breeze, 707 S.W.2d 298 (Tex. App.-Fort Worth 1986, writ dism'd w.o.j.) (sex bias in division on divorce); Carley v. Carley, 705 S.W.2d 371 (Tex. App.-San Antonio 1986, writ dism'd w.o.j.) (measure of reimbursement); Zisblatt v. Zisblatt, 693 S.W.2d 944 (Tex. App.-Fort Worth 1985, writ dism'd w.o.j.) (character of incorporated personal service business); Estate of Korzekwa v. Prudential Ins. Co., 669 S.W.2d 775 (Tex App.-San Antonio 1984, writ dism'd w.o.j.) (constructive fraud and reimbursement); Frausto v. Frausto, 611 S.W.2d 656 (Tex. Civ. App.-San Antonio 1980, writ dism'd w.o.j.) (professional skill as separate or community property); Horlock v. Horlock, 533 S.W.2d 52, 60-61 (Tex Civ. App.-Houston [14th Dist.] 1976, writ dism'd w.o.j.) (gift of community as alleged constructive fraud). See also Moreno v. Alejanero, 775 S.W.2d 735 (Tex. App.-San Antonio 1989, writ denied) (division of tort recovery undivided on divorce); Andrle v. Andrle, 751 S.W.2d 955 (Tex. App.-Eastland 1988, writ denied) (characterization of post divorce payments under structured settlement for tortious injury during marriage); Dewey v. Dewey, 745 S.W.2d 514 (Tex. App.-Corpus Christi 1988, writ denied) (character of alleged gift).

163. TEX. REV. CIV. STAT. art. 1821(4) (1925) (codified as amended at TEX. Gov't CODE ANN. § 22.225 (West 1988)). See also TEX. Rev. CIV. STAT. art 1728(1)-(3), (6) (1925) (codified as amended at TEX. GOV’T CODE ANN. \& 22.001(a)(1)-(3), (6) (West 1988)).

164. See McKnight, supra, note 9, at 33 n.24, 53 n.145.

165. Hilley v. Hilley, 324 S.W.2d 565 (Tex. 1961).

166. Horlock v. Horlock, 533 S.W.2d 52 (Tex. Civ. App.-Houston 1976, writ dism'd w.o.j.). See also Carnes v. Meador, 533 S.W.2d 365 (Tex. Civ. App.-Dallas 1975, writ ref'd n.r.e.); Givens v. Girard Life Ins. Co., 480 S.W.2d 421 (Tex. Civ. App.-Dallas 1972, writ refd n.r.e.).

167. Land v. Marshall, 426 S.W.2d 841 (Tex. 1968). The petitioner's counsel had conceded that fraud was not in issue. 
During the past twenty years, the court has periodically dealt with disputes concerning community property left undivided on divorce. ${ }^{168}$ This series of decisions nicely illustrates the process by which judicial handling of a particular issue has served as a catalyst to legislative reform. The most common subject matter of such disputes in all the appellate courts has been a former spouse's retirement benefits, overlooked by the divorce court because the pensionerspouse had not yet retired. After concluding in 1970 that the nonpensioner exspouse was not barred from recovery by the doctrine of res judicata and was therefore entitled to an undivided half of a vested community pension interest, ${ }^{169}$ the court went on to hold that an interest contingent at divorce but subsequently vested should be handled in the same way. ${ }^{170}$ In that instance, the court held that the community portion of the pension interest (acquired over a period during which the pensioner was married for a while and single for the rest of the time) was computed by a ratio of the number of months of marriage to the entire number of months of employment. Focusing on the amount of the nonpensioner's ex-spouse's recovery in 1983, the court reasoned that the nonpensioner's share was merely half the value of the community interest on divorce (as though the pensioner had retired at that time) rather than the value reckoned by applying the ratio of the number of months of marriage to those during which the entire interest accumulated. ${ }^{171}$ The court, therefore, omitted from the calculation the value of the nonpensioner's interest from the date of divorce to the date of a postdivorce judgment. In the case before the court, however, that amount was merely alleged but not proved. In a later case, ${ }^{172}$ the court recognized the nonpensioner's right to postdivorce cost-of-living increases in undivided pension benefits with the implication that other postdivorce increases in value would also be recognized.

In response to this series of judicial opinions, the legislature in 1987 provided a simpler (but only partial) solution to the problem of undivided community interests: If recovery is sought within two years of an unequivocal denial of the right to an undivided interest, the divorce court may make an equitable division of the interest (rather than an equal partition) ${ }^{173}$ Unresolved in this course of development is a clear determination of the burden of proof to show the value of the competing separate and former community interests and their enhance-

168. The related problem of distinguishing between community properties of successive marriages had been dealt with in Tarver v. Tarver, 394 S.W.2d 780 (Tex. 1965). The first community was not divided on the death of the first wife. After the husband's second marriage and divorce, the second wife sued for a division of the second community and prevailed over the ex-husband and his children of the first marriage by application of the community presumption.

169. Busby v. Busby, 457 S.W.2d 551 (Tex. 1970).

170. Taggart v. Taggart, 552 S.W.2d 422 (Tex. 1977); Cearley v. Cearley, 544 S.W.2d 661 (Tex. 1976).

171. Berry v. Berry, 647 S.W.2d 945 (Tex. 1983). The court relied heavily on Herring v. Blakeley, 385 S.W.2d 843 (Tex. 1965), where the court had said that the value of an ex-spouse's community interest in a profit-sharing plan earned by the other ex-spouse and payable on termination of his employment (which occurred on his death) was determined at that time.

172. Grier v. Grier, 731 S.W.2d 931 (Tex. 1987).

173. TeX. FAM. CODE ANN. $\$ \$ 3.90-3.93$ (West 1993). 
ment in value. In these instances, the community presumption is not applicable because the community estate terminated on divorce and became a tenancy in common of separate interests. ${ }^{174}$ Furthermore, despite a developing group of Texas Supreme Court decisions and a number of inharmonious decisions from the intermediate appellate courts dealing with the division of federal pension rights $^{175}$ affected by the Uniformed Services Former Spouses Protection Act, ${ }^{176}$ legislative guidance in handling that subject has not been proposed.

\section{$\mathrm{V}$ \\ CONCLUSION}

One of the greatest difficulties in pursuing law reform in the legislature (as well as in the courts) is to overcome each legislator's (or judge's) inclination to consider every proposal or argument in the light of his or her familial situation. In the legislature, the size of the deliberative body and the pressure of other matters thought to be of more immediate importance contribute to overcoming individual concerns, but in the courts the factor of personal interest frequently produces inconsistency in appellate decisions. ${ }^{17}$ Because law reform has been much more effectively pursued in the Texas legislature than in the courts, and because of the leadership provided by the bar, Texas family property law has been greatly modernized during the last twenty-five years, including necessary alterations of the constitution. Although Texas stands alone among American jurisdictions in ultimately regulating her family property law at the constitutional level, the availability of constitutional restraint to allow judicial oversight of legislation continues to be regarded as a desirable aspect of Texas law. Even so, the legislature and its professional advisers sometimes cannot resist the temptation to challenge the supreme court to rule on the constitutionality of a dubious proposition. ${ }^{18}$ On occasion the court has followed the legislative initiative, and the court's rejection of a legislative solution has also prompted constitutional reform.

174. Busby, 457 S.W.2d 551.

175. See Allison v. Allison, 700 S.W.2d 914 (Tex. 1985) (per curiam); Cameron v. Cameron, 641 S.W.2d 210 (Tex. 1982); Trahan v. Trahan, 626 S.W.2d 485 (Tex. 1981); Segrest v. Segrest, 649 S.W.2d 61 (Tex. 1983), cert. denied, 464 U.S. 894 (1983); Berry, 786 S.W.2d 672.

176. 10 U.S.C. $\$ 1408$ (1989) (originally effective Feb. 1, 1983).

177. When one considers that two cases as different in analysis as Graham v. Franco, 488 S.W.2d 390 (Tex. 1972), and Nail v. Nail, 486 S.W.2d 761 (Tex. 1972), were decided by the same court on the same day, one also appreciates the possibility that a differently constituted court may see a later dispute similar to one of those from a different perspective.

178. For recent examples, see TEX. REV. CIV. STAT. ANN. art. 4610 (West 1967); TEX. FAM. CODE ANN. $\$ 5.41$ (West 1969 and 1981); and TEX. FAM. CODE ANN. \& 5.43(a)(1) (West 1987). See supra notes 118-22 and accompanying text. 